\title{
BUSINESS MODELS IN PERSPECTIVE OF "NEW NORMAL" BUSINESS ENVIRONMENT
}

\author{
Aleksandra Živaljevićí, \\ Ana Jovancai Stakić ${ }^{2}$ \\ ${ }^{1}$ Higher Colleges of Technology, \\ United Arab Emirates \\ ${ }^{2}$ Singidunum University, \\ Belgrade, Serbia
}

\begin{abstract}
:
Modern science produced remarkable opus of knowledge in management. However, all concepts, theories and models assumed certain characteristics of economy and business environment. COVID-19 influenced dramatic changes and disruptions in all aspects known to us imposing questions of existing business models suitability. Paper discusses the characteristics of post-covid business environment and stresses the challenges that existing business models might face in the "New Normal" World.
\end{abstract}

\section{Keywords:}

post-Covid environment, business models, unemployment, purchasing power.
Correspondence:

Aleksandra Živaljević

e-mail:

azivaljevic@hct.ac.ae

\section{INTRODUCTION}

Science holds a wide opus of different business models for maximizing the company's performance. Each of those models tend to assure company's continual success at the market (Magretta, 2002) and the maximization of its profit (Khan, 2017), but also most of these models tend to make companies ready for the changes in the environment (Schneider \& Spieth, 2014).

Most of the papers characterize business reality of $21^{\text {st }}$ century as "turbulent" referring predominantly to two aspects. First, changes are constant and inevitable part of business environment. These changes relate to technological development, which offers new opportunity for companies' processes performance, as well to the constant changes at the market that originate from constant appearance of new needs and requirements of customers. Second, there is high uncertainty of directions and effects of changes, which means that there is high incapability to forecast the nature of the future changes. The technological development rate is extremely high and it constantly exponentially increases, resulting in, sometimes, opposite estimations about the available technology in the future, about the timings and about the nature of the needs on the market influenced by technological development. All business models tend to ensure companies' existence and growth in such circumstances and most of them have been proven to be suitable for such environment until pandemic appeared.

The beginning of early 2019 brought shocking change to the World. Globalization and technological development caused spreading of the disease in every part of the World. Environment we knew before the COVID-19 outbreak suddenly became the past. 
Most of research studies (conducted since the beginning of pandemic) testify that COVID-19 brought major disruptions to all segments of reality - affecting dramatically individuals, families, companies, industries and countries. This kind of economy disruption have not been seen in the history of civilization, since the whole World was affected at the same time going into mass lockdowns or decreasing life activities to a minimum.

We may witness now, 20 months since the beginning of the pandemic, that some companies did not survive while some are still struggling to cover the loses. The shape of the World economy changed as well, since some countries changed their policies, strategies and the course of economic growth.

Still, the end of pandemic is not near and the world is trying to cope with it. The two questions are: What are characteristics of the current economic environment and how it will be shaped once the pandemic is over? These two questions are closely connected to everything we knew so far because if the World is going to be changed completely, than all we learned and invented might not be suitable anymore.

\section{BACKGROUNDS}

The term "business model" firstly appeared in Bellman et al. (1957) (Wirtz et al, 2016) as a name for the set of mathematical equations which should be used to describe model of business situation (see: Bellman et al., 1957). Today, business models assume wide range of different representations of a company's structure (Al-Debei et al, 2008)), but also they refer to theoretical concepts, which are defined and broken down into its components (Wirtz et al, 2016). A variety of business models imposed the need for their classification, therefore different proposals and approaches to business models classifications can also be found in the literature while none of proposed classifications stood out as a general validity (Nisa \& Ravichandran, 2013). However, common to all business models is that each model (Adrodegari et al., 2016; Klueber, 2005):

- Structures the business system through stressing important elements which create the value

- Links a company to its market

- Links a company to its network of suppliers

The structure of business system assumes that core processes use employees' knowledge and skills to result in value for the customer. Additionally, feedback plays a crucial role to decision makers who use the information obtained from different parts of business system, as well as from the market, in order to direct adjustments to changes in the environment. Although not particularly mentioned in each model, knowledgeable and skilled human resources are indispensable part of each business model and company itself (see: Kim, 2015). Another desirable characteristic of business structure - the flexibility of processes relies on knowledge and skills of employees (Bellinger, 2014).

The market consists of customers (individuals or companies) who define the value (Kuzieva, 2020) and who are capable and willing to pay for products and services (Kreuzer et al., 2020) a company produces. Therefore, they are the source of company's profit. Each business model assumes that customers have certain needs which the company should satisfy with a particular set of service and product features which the company offers on the market with acceptable price. Customers' needs are assumed to be changing over time, but the needs for products and services which the company offers is constant. The changes in needs refer to the features of products and services. The changes of needs are assumed to be learnable for the company, otherwise the market niche would not be satisfied. Therefore, all business models assume purchasing power and the needs for products and services.

A network of suppliers consist of companies which are capable to deliver goods or services to the company in time and quality necessary for further value creation. Delivering material in a timely manner and of desirable quality is imperative for smoothness in production flow as well as for cost optimization. When supply uncertainty increases, than the company tends to find ways to assure availability of the necessary supply (Zhang, 2013). The availability of supply and the level of supply uncertainty depend on the reliability of supply distribution, among the other factors (Pan \& So, 2016). Furthermore, the distribution of supplies uses transport modes to make material available at a needed location, at a needed time and of needed quality. The availability of transport, as well as the existence of necessary material is considered to be the assumption of all business models. And here we come to the fundamental question:

Are there markets with purchasing power and availability of supplies and resources for companies in post covid environment?

\section{POST-COVID-19 BUSINESS ENVIRONMENT FRAME}

The World Health Organization (WHO) declared a Public Health Emergency of International Concern on 30 January 2020, and a pandemic on 11 March 2020 (Peden \& Kobusingye, 2019). By April 2020, about half of the world's population was under some form of lockdown, with more than 3.9 billion people in more than 90 countries or territories having been asked or ordered to stay at home by their governments (Sandford, 2020). 
The majority of companies in lockdown countries were forced to stop all activities while the companies in the countries which avoided imposing the lockdown, suffered consequences of insufficient resources, delays in supplies and difficulties in delivering products and services to the market. Economic activities declined (Onyele \& Nwadike, 2020) all around the World which resulted in remarkable financial losses for majority of companies (Jaina \& Vermab, 2020; Zahariev et al., 2020; Ahsany et al., 2020). About 1.9 million small businesses got in immediate risks of getting closed (Kyung \& Whitney, 2020). More than 22 million employees filed for unemployment (Kyung \& Whitney, 2020) which directly influenced decrease in purchasing power on the market.

While hospitality, aviation and events industries become the main losers during pandemic, the business areas necessary to facilitate remote working, online education and supply of essential goods and services recorded explosive growth (Anker, 2021). Pandemic affected some industries for the foreseeable future and changed the meaning of work, business, leadership, entrepreneurship and consumption (Anker, 2021).

An observation published by Deloitte (Bachman, 2020) argues that COVID-19 could affect the global economy in three main ways:

- directly affecting production,

- creating supply chain and market disruption and

- affecting companies and markets financially causing major shifts in demand i.e. resulting in unprecedented changes in consumer behavior as well as in their purchasing power .

Anker (2021) argues that pandemic brought fundamental changes in three different areas: consumer behavior, supply chain management, and political CSR stressing the need to review what it means to do business in 'the new normal'.

\section{DISCUSSION}

All companies need supplies, resources and markets to operate. Supplies became an issue during the pandemic since some of suppliers either closed down or were not able to export their goods using old traffic modes and routes. Companies naturally turned to suppliers near them if those existed. This turned global orientation of business back to local again causing that supply chains restructure overnight. One more fact became clear: uncertainty of supplies is high all around the world. Therefore, only business models which assume high level of uncertainty at suppliers markets may bring benefits to companies.
Companies which were able to work remotely saw that this way of functioning cuts costs drastically (Saludin et al., 2020). Also, most of the companies decreased a large number of employees making those who stayed work much longer hours while their job entailed additional activities and responsibilities. However, their salaries stayed the same or decreased because company needed to cut the costs. Purchasing power at the market decreased drastically since those who had incomes before the pandemic lost them during the pandemic and those who stayed employed in most of the cases received lower salaries. The feeling employment uncertainty influenced those with income to save rather than spend their money. Therefore, the current market consists of less customers with buying power who are not willing to buy in the same extent and frequency as before. The unemployment rate will continue to increase (Lai, 2021; Ahmad, 2021; Chen, 2021) as a consequence of further decline in the number of vital companies at the market and as a consequence of replacing employees with technology. If this loop continues, companies might lose the purpose to exist. This imposes the need for a new economic model, which would allow all people to have basic income resulting not from their work or ownership, but from the fact that they are alive. If this does not happen and companies lose purpose to produce, this could be the end of civilization we know. However, if new economic model is invented and applied, then new or improved business models have to acknowledge the link between governments and companies and make them manageable.

The trend in relying on automation and technology to do the job may result in increased number of companies with fully automated processes and no human beings in them. This would jeopardize the flexibility of companies to adjust and change, making them vulnerable to turbulent environments. This imposes the need for the new or improved business model, which would find a way to assure flexibility in employee free companies and make them able not only to improve features of their products or services but also to introduce new products and new processes.

\section{CONCLUSION}

To state that the world has been changed by the COVID-19 pandemic is so obvious, however some of researchers claim that there will be no return to the pre-COVID-19 state, and that serious thought should be given to the new world (Jones, 2021). The new world with new characteristics of business environment sets the challenge before the scientists, practitioners and experts to research economic models which would assure existence of purchasing power at the market, as well as the business models which would manage to assure flexibility of employee free companies. 


\section{LITERATURE}

Adrodegari, F., Saccani, N., \& Kowalkowski, C. (2016). A framework for PSS business models: formalization and application. Procedia CIRP, 47, 519-524.

Ahmad, M., Khan, Y. A., Jiang, C., Kazmi, S. J. H., \& Abbas, S. Z. (2021). The impact of COVID-19 on unemployment rate: An intelligent based unemployment rate prediction in selected countries of Europe. International Journal of Finance \& Economics.

Ahsany, F., Alamsyah, A. F., \& Al-Fatih, S. (2020). Legal Protection of Labor Rights During the Coronavirus Disease 2019 (COVID-19) Pandemic. Jurnal Pembaharuan Hukum, 7(2), 100-115.

Al-Debei, M.M., El-Haddadeh, R.E., Avison, D. (2008). Defining the Business Model in the New World of Digital Business. Americas Conference on Information Systems 2008, Proceedings Paper 300, Toronto (2008)

Anker, T. B. (2021). At the boundary: Post-COVID agenda for business and management research in Europe and beyond. European Management Journal, 39(2), 171-178.

Bachman, D. (2020). The economic impact of COVID-19 (novel coronavirus). Deloitte Insights. Accessed, 28.

Bellinger, G. (2014). ICT big size projects in Outsourcing with BPR. The agile scenario. Academic vs actual dynamics and effectiveness in a prone to uncertainty environment (Doctoral dissertation, The University of Liverpool).

Bellman, R., Clark, C.E., Malcolm, D.G., Craft, C.J., Ricciardi, F.M., 1957. On the construction of a multi-stage, multi -person business game. Operations Research, 5(4), $469 \mathrm{e} 503$.

Chen, Y. (2021, June). Causes and Countermeasures of Unemployment Rate in the Middle and Later Period of Epidemic. In 2021 International Conference on Enterprise Management and Economic Development (ICEMED 2021) (pp. 118-124). Atlantis Press.

Jaina, K. R., \& Vermab, N. (2020). COVID-19 and Financial Markets of Indian Economy-A Review. International Journalof Trade \& Commerce-Iiartc, 10.

Jones, D. G. (2021). Anatomy in a post-COVID-19 world: Tracing a new trajectory. Anatomical Sciences Education, $14(2), 148-153$.

Khan, Z. A. (2017). Profit maximisation as an objective of a firm - A robust perspective. International Journal of Research in Finance and Marketing, 7(6), 217-219.

Kim, L. S. (2015). Components of a Business Model and their influences on a firm performance. Indian Journal of Science and Technology, 8, 139.

Klueber, R. G. (2005). Frameworks and models to identify and increase the success potential of e-services. University of Surrey (United Kingdom).

Kreuzer, T., Röglinger, M., \& Rupprecht, L. (2020). Customercentric prioritization of process improvement projects. Decision Support Systems, 133, 113286.
Kuzieva, N. (2020). Kuzieva Nargiza Ramazanovna Busıness Processes In The Insurance System And Their Features. Архив научных исследований, (24).

Kyung, A., \& Whitney, S. (2020, September). A study on the financial and entrepreneurial risks of small business owners amidst covid-19. In 2020 IEEE International IOT, Electronics and Mechatronics Conference (IEMTRONICS) ( pp. 1-4). IEEE.

Lai, H., Khan, Y. A., Thaljaoui, A., Chammam, W., \& Abbas, S. Z. (2021). COVID-19 pandemic and unemployment rate: A hybrid unemployment rate prediction approach for developed and developing countries of Asia. Soft Computing, 1-16.

Magretta J. (2002). Why business models matter. Harvard Business Review, 80 (5), 86-92.

Nisa, S., \& Ravichandran, N. (2013). Business Model: Concept and Evolution. Amity Global Business Review, 8.

Onyele, K. O., \& Nwadike, E. C. (2020). Dynamics of Stock Returns Amidst COVID-19 Lockdown: A Descriptive Analysis of Global Stock Markets. Dynamics, 6(12), 18-26.

Pan, W., \& So, K. C. (2016). Component procurement strategies in decentralized assembly systems under supply uncertainty. IIE Transactions, 48(3), 267-282.

Peden, M., \& Kobusingye, O. (2019). Transport and health during and after COVID-19: An Insight. Health.

Saludin, N. A., Karia, N., \& Hassan, H. (2020). Working from Home (WFH): Is Malaysia ready for digital society. In Entrepreneurship Vision 2020: Innovation, Development Sustainability, and Economic Growth-Proceedings of the 20th International Business Information Management Association Conference, IBIMA 2013 (pp. 981-989).

Schneider, S., \& Spieth, P. (2014). Business model innovation and strategic flexibility: insights from an experimental research design. International Journal of Innovation Management, 18(06), 1440009.

Sandford, A. (2020). Coronavirus: half of humanity on lockdown in 90 countries. https://www. euronews. com/20, 20(04), 02.

Wirtz, B. W., Pistoia, A., Ullrich, S., \& Göttel, V. (2016). Business models: Origin, development and future research perspectives. Long range planning, 49(1), 36-54.

Zahariev, A., Prodanov, S., Zaharieva, G., Krastev, L., Kostov, D., Pavlov, T., ... \& Zdravkov, N. (2020). The Brokerage Insurance Companies Under COVID-19 Framework (The Bulgarian Experience). Economic and Social Development, 58 .

Zhang, D. (2013). The revival of vertical integration: strategic choice and performance influences. Journal of management and strategy, 4(1), 1. 